\title{
The Challenges of Youth Empowerment through Access to Credit in the Rural Areas of Nigeria
}

By

\author{
${ }^{1}$ Haruna Mohammed Aliero (PhD) and ${ }^{1}$ Saifullahi Sani Ibrahim (MSc.)
}

\begin{abstract}
Unemployment and poverty are endemic among Nigerian youth in spite of numerous approaches to curtail the menace Access to credit is critical to enable the poor to transform their production systems and thus exit poverty. It is a well known fact that an efficient financial sector that responds to the needs of the private sector increases investment, enhances economic growth, and creates job opportunities which is one of the major challenges for developing economies. This paper examines the role of credit deepening on youth empowerment and poverty reduction in Nigeria. The approach of the paper is qualitative and uses content analysis; literature was reviewed and thereafter conclusion was drawn based on the literature weight. It is however important to note that economic empowerment through accessibility to credit could be achieved if and only if factors like collateral, interest rate, transaction cost and financial literacy, among others that pose challenges in accessing credit are remedied Specifically we recommend Indian model (Bharatia Yuva Shakti).
\end{abstract}

Key word: youth empowerment, poverty, access to credit, youth unemployment, collateral

\section{Introduction}

Youth employment has grown in prominence on national and global development agendas. The youth employment challenge has its own dimensions and confronts countries worldwide regardless of their stage of socio-economic development. The underlying problems are the large number of young people entering the labour markets every year, the lack of employment opportunities in particular in poor economies and post-conflict countries, and the low quality of education and training without a proper link to the labour markets (Coenjaerts et al, 2009). Despite an impressive annual growth rate of more than $5 \%$ in recent years and commendable progress achieved in the area of education, Africa has been unable to significantly expand

${ }^{1}$ Department of Economics Faculty of Social Sciences Usmanu Danfodiyo University Sokoto

${ }^{2}$ Department of Economics, Umar Musa Yar'adua University, Katsina Katsina State. 
employment opportunities for young people. The African Development Bank (AfDB) (2011) reported that about $70 \%$ of Africa's population is aged below 25years, while about $37 \%$ of their labour are youths. The youth constitute $60 \%$ of the total unemployment in Africa. The problem is compounded because many young people are lacking in relevant skills while those that have some form of education often exhibit skills that are not at odds with current demand in the labour market. Hence, paradoxically, African countries are increasingly experiencing the phenomenon of educated unemployed resulting from mass education. The Bank also stated that about 5million graduates are produced annually by African Universities with many displaying low employment capacities when they enter the labour market.

Addressing the menace of youth unemployment is one of the daunting challenge facing successive governments in Nigeria. This is certainly in recognition of the fact that youth empowerment is an important issue to economic growth and development. Youth represents group of people with limited portion of life to contribute immensely toward expanding the production possibility frontier of their country. This is so if their skills are harnessed and effectively put into productive uses. It is however worthwhile to note, that limited portion of life is the irreversible youth age (Jimba, 2007). Unlike the productivity of capital, human capability diminish with age, as such, if not previously utilized, the preceding productivity cannot be brought to use at a later stage and so the end result will be prevalence of unwanted social disorder such as political thuggery, kidnapping, delinquency and prostitution, among others (Ibrahim, 2011).

There is an old saying base on resources endowed in the country that Nigeria is too rich not to be poor but reverse is the case as what is obtaining is that the country is too poor not to be rich. Unsurprisingly, over two-third of Nigerians are poor and majority of whom are youth that are pathetically living in hopeless and helpless condition. It is a well known fact that, ssocieties that fail to acknowledge the particular challenges facing youth and involve them in decision making will find it difficult to achieve the Millennium Development Goals (MDGs) especially, goal number one which is concerned with reductions in poverty levels at least by half by 2015 (World Youth Report 2005).

The issue of youth empowerment and leadership is gaining increasing importance in the development agenda of national governments, regional entities and international development organizations. Most notably, there is a new momentum to promote the participation of youth groups and non-government organizations (NGOs) in a wide range of policy dialogues and policy development initiatives to ensure that opinion of youth are also recognized in governance. In fact, the economic role of the youth is so important that it is enumerated as Target 16 of Goal Number 8 of the MDG where it states interlia: Develop a Global Partnership for Development: in cooperation with developing countries, develop and implement strategies for decent and productive work for youth.

Empowering the poor youth with education does not only give them access to good employment but also gives them access to information which they can use to take advantage of market opportunities (IPAR, 2007). It has been argued that lack of market 
information and therefore, inadequate access to finance by the poor youth, is one of the main reasons why they remain poor. It is in this regard that Burgess and Pande (2003) argued that access to credit is critical to enable the poor to transform their production systems and thus exit poverty. Access to finance through credit assists the poor not only to smooth their consumption but also to build their assets, which enhance their productive capacity (IPAR, 2007). Against this background, this study intends to analyse the challenges of access to finance as a veritable tool for youth empowerment in Nigeria, with a special focus on rural areas. To achieve this objective, the paper is divided into five sections including this introduction. Section two reviewed the situation of unemployment in Nigeria, section three presents the effect of access to credit on youth empowerment and poverty reduction while section four contains challenges of access to credit on poverty reduction and the fifth section concludes the paper.

\section{Effect of Access to Credit on Youth Empowerment and Poverty Reduction}

The literature addressing the question of whether finance creates growth (e.g., Hicks, 1969) or follows growth (e.g., Robinson ,1952) is vast, and dates back at least as far as Schumpeter (1912). There is ample evidence showing a strong and causal relationship between financial sector development and economic growth. An efficient financial sector that responds to the needs of the private sector increases investment, enhances economic growth, and creates job which is one of the major challenges for developing economies (Nasr, 2006). Improving households' access to financial services will also help to reduce poverty and improve income equality while financial exclusion can retard economic growth and increase poverty and inequality (Butler and Cornaggia, 2008). Robust economic growth cannot be achieved without putting in place well focused programmes to reduce poverty through empowering the people especially youth by increasing their access to factors of production (CBN, 2005). The capacity of the poor would be significantly enhanced through the provision of financial services more especially credit to enable them engage in economic activities and be more self-reliant, increase employment opportunities, enhance household income thereby leading to the youth empowerment.

Youth empowerment has been recognised as a catalyst for achieving pro-poor growth among the Less Developed Countries (LDCs). This led Sacerdoti (2005) to argue that faster economic growth will not be possible without deepening of the financial system and, in particular, more support from the banking system. He further showed that there is strong association between access to bank credit and overall economic development of a country. Access to finance can help poor youth to increase income, build viable business, and reduce their vulnerability to external shocks. It can also be a powerful instrument for self-empowerment by enabling the poor, especially youth, to become economic agents of change (Bashir, 2008). As noted by De la Torre and Schmukler (2006), the discussion of the plausible channels through which financial depth could cause economic empowerment often resorts to access related stories. Prominent in this regard is the Schumpeterian view that finance lead to growth because it reduces creative 
destruction by allocating resources to efficient newcomers. That is through broader access to external funds, talented newcomers are empowered and freed from the disadvantages that would otherwise arise from their lack of inherited wealth and absence of connection to the network of well off incumbents (Rajan and Zingales, 2003).

Aggregate economic growth and efficiency are influenced by financial transaction in their role in agglomerating capital, selecting projects most likely to yield the highest return, monitoring borrowers (investors), enforcing contracts, transferring, sharing, and pooling risk, and promoting diversification (Stiglitz, 1993). An expansion of the supply of agricultural credit will have a better chance of success if it is embedded in effort to improve the performance of rural financial market and in effort to achieve greater market integration and more rapid economic growth in the rural areas (Gonzalez-Vega, 2003). The ability of the poor to borrow a small amount of money to take advantages of a business opportunity not only impacts positively on eradication of poverty but also tend to swell the rank of micro-entrepreneurs (Egwuatu, 2008). The supply of efficient, sustainable, and broadly-based financial service is particularly important in rural areas, giving high risks and transaction costs in most rural markets for goods, services, assets, and factors of production, which result in large degrees of market fragmentation that is, the costs and risk are responsible for low level of market integration and for a wide dispersion of the marginal rates of return on resources used (Mckinnon, 1973).

\section{Challenges of Access to Credit on Poverty Reduction}

The growing interest in financial deepening has been an interest in poverty alleviation. Though, the relationship between poverty and finance is quite complex, it is most important to recognize that, despite major earlier attempts to expand the supply of agricultural credit and despite the massive use of public funds for this purpose, the majority of the youth, especially in the rural areas of the developing countries have actually never had access to formal financial services (Gonzale-vega, 2003). Thus, the basic question is; why has the youths not had adequate access to formal financial services, despite their legitimate demands, for various types of loans, deposit facilities and other financial product. Some of the factors identified in the literature are explored below:

\subsection{The Tyranny of Collateral}

It is widely acknowledged that for bank intermediation to deepen it is necessary that collateral is sufficiently available to borrowers and enforceable to lenders (Sacerdoti, 2005). One way in which a financier can reduce the risk of losing his money due to uncertainty is by requiring collateral. Collateral reduces the problem of uncertainty, since the lender can theoretically recover some, or all, of his loan in the event of nonrepayment. It also reduces information asymmetries; it is often easier to value physical assets than to value character. Moreover, the borrowers will find it very costly to mortgage their valuable collateral if they intend to default, because they certainly know defaulting implies forfeiting the asset so mortgaged. Thus, the collateral requirement can 
also help to weed out rogues from honest borrowers, leaving only bona-fide applicants who genuinely ready to repay the loan. The potential loss of their collateral also makes the borrower think twice before investing in very risky ventures (Basu, 2006).

Unfortunately, most people in developing countries are living in abject poverty, they do not own assets that are acceptable as traditional collateral on loans, this hinders financial access to the rural poor (Fleising and De la Pena, 2003). Besides, collateral realization processes are often very weak in Sub-Saharan Africa (SSA), this as a barrier to credit protection, was aggravated by the fact that in many countries the process of issuance of tittles is extremely low, due to the absence of appropriate procedures for registration of properties, and inadequate facilities in the registration offices (Sacerdoti, 2005). It is apparently clear that a poor-youth typically do not have collateral, so they lose out once again. Another problem is that collateral can only provide security to lenders in an environment where households have proper titles to their assets, and where the legal system makes it relatively straight forward for lenders to enforce contracts and repossess collateral ( Basu, 2006). In most of the LDCs property rights and titles, particularly, in the rural areas are generally lacking or not clear.

\subsection{Financial Literacy}

It has been observed that financial institutions in developing countries appear inaccessible to youth dwelling in rural areas because not only they are sparsely populated but also because they lack adequate critical financial knowledge that is essential for financial intermediation in the area (Beck and La Torre, 2006). For example, Ladipo (2008) argued that rural poor in Nigeria are excluded from mainstream financial institution because they are highly illiterate. The level of literacy in Nigeria is still less than $50 \%$, and it is argued that formal education has a direct correlation with financial literacy (Sancho, 1996; Babasanya et al., 2008). Specifically, women however, take the disproportionate burden of financial illiteracy. Devkota (2006) argued that women were largely illiterate and thus were not involved in financial activities that need specific knowledge and skills, and requires information. This problem constitute a serious constraint to the youth in accessing formal credit (Todaro, 2000)

\subsection{Transaction Costs}

Transaction costs of rural lending in developing countries are high, mainly due to small loans size, high frequency of transactions, large geographical spread, the heterogeneity of borrowers as well as the lack of rural bank branch network as additional problem (Sercadoti, 2005). Given the extent of rural poverty in developing countries, the amount of financial services required tends to be small. The small size of rural loans, resulting in a high transaction cost per loan, exacerbated by the heterogeneity of borrowers, makes it difficult for formal financiers to cover costs. The geographical spread of customers in rural areas further drive up administrative costs after the loan is granted (Olayide et al., 1980). Borrower supervision costs are high, as are compliance costs for customers. Financiers thus, have to achieve a delicate trade-off between minimizing the loan default rate and minimizing administrative and collection costs (Basu, 2006). 
The effect of transaction costs on financial service provision can be reinforced by network externalities, where the marginal benefit to an additional customer is determined by the number of customers already using the service (Classens, Dabos, Klingabile and Leavine, 2003). This is specifically relevant for payment systems, where benefits and demand increase as the pool of users expands. High transaction cost can trap a small financial system at a low level equilibrium because of the system's inability to reap the necessary scale economies and network externalities. Because of scale economies and network externalities, problems of access to payment and savings service in many developing countries are related to the oft-found triple problem of smallness - small transaction, small financial institution, and small market size (Beck and la Torre, 2006). In a "friction-less" world (i.e. one without asymmetric information and transaction costs) financial intermediation is not problematic and therefore the question of distinguishing between "good" and "bad" borrowers does not arise. All that matters then is whether a project is profitable or not. However, in reality, frictions prevail and lenders need to collect information about potential borrowers. Information being costly, it may be assumed that lenders try to minimize the costs involved in information-gathering (Anders, 2002). Unless a way is found to raise transaction volume to size scale economies, low-income clients with the need for small and few payment transaction would not constitute a profitable clientele for financial service provider.

\subsection{Socio-economic Challenge}

More often gender and age were stressed in the literature among the factors that constraints access to credit especially in developing countries. Sabopetji and Belete (2009) argued that men customers have more access to finance than their women counterparts. Women are mostly poor and illiterate; perhaps they lack critical collateral to use for sourcing credit. They further reveal that over $90 \%$ of rural women had no access to formal financial services in rural South Africa. Similarly, Kaino (2005) discovered an insignificant proportion of women accessing financial services in rural Myanmar. It has been argued that, access to finance has the capacity to change women positively thereby enabling them to participate in productive economic activities and have control over their assets ((Naved, 1994; Zaman, 1999).

On the other hand, age also poses considerable challenge to access to credit in Developing countries. Researchers revealed different direction about the influence of age on access to finance. On the one hand, Sabopetji and Belete (2009) contend that decision to take credit decreases with household age i.e. there is negative significant influence of age on access to finance. On the other hand, Kaino (2005) observed that age has a significant positive effect on access to finance implying that youths have greater chance of securing formal credit than ageing people. However, the reality is that youth in the lower age bracket $(15-25$ years $)$ hardly get loan in developing countries.

\subsection{Interest Rate}

Another factor that exerts considerable challenges to access to credit is the rate of interest. Keynes argued that, investment is a decreasing function of interest rate. This implies that whenever interest rate rises up, investment will eventually fall, this is because with higher interest rate the possibility of making profit out of investment is very low, 
hence high interest rate reduces the marginal efficiency of capital. Therefore as a rule of thumb, investors will like to borrow from banks at a lower interest rate.

On the contrary, bank charges interest to investors out of which certain percentage will be paid to savers as deposit rate. At higher deposit rate, saving will be attractive and similarly banks will extend more loans, but investors will reject further loans as interest rises. Higher interest rate discourages rural poor to deepen their financial access. Interest rates are very higher in developing countries especially, on micro-credits due to the higher administrative costs in relations to their scale of operations (Sacerdoti, 2005). It is very obvious that higher interest rates discourage borrowing.

\section{Conclusion and Recommendation}

Robust economic growth cannot be achieved without financial deepening especially to the rural youth of developing countries. This will in turn free them from difficulties of lack of technical backstopping required for creativity. Access to credit especially, among youths could ensure that the youth are fully employed without any serious burden on the government, in addition once the credit so extended has been put into productive use they are sure of a reliable source of income which will in turn add to aggregate income, in the same vein, we are also limiting the social evils of youth unemployment. Possession of collateral is one of the major obstacles to the youths' access to finance; it is hereby recommended that an alternative arrangement for securing loans in the rural areas be initiated. In order to overcome these factors constraining the Nigerian youths from accessing formal bank credit, it is recommended that a special fund be created by the government. The fund should be entrusted with Microfinance banks in the country, which shall in turn extend the credit to desiring youths after assessing their application. We can also borrow the leave from the Bharatia Yuva Shakti (BYST) of India, which was launched in 1992. The main aim of the program was to help youths aged 18-35 to start business of their own. BYST provide the fund and business network as well as one-to-one mentoring (Subrahmanyam, 2011).

\section{Reference}

African Development Bank (AfDB) (2011) Enhancing Capacity for Youth Employment in Africa: Some Emerging Lessons, African Capacity Development Brief, Vol. 2 Issue 2 December

Anders, I.(2002). Access to Formal Finance in Kenyan Manufacturing. Sin Working Paper Series. W/p No.3. Pp3-29.

Babasanya, B., Bolagun, O., Zungum, A. and Olowohunwa, J. (2008). Rural Development: An

Approach to Poverty Alleviation in Nigeria. International Journal of Economics and Development, Universal Consortia. Pp.28-41.

Bashir, U. (2008). Overview of Credit Delivery Channels in Nigeria. Bullion Publication of Central Bank Of Nigeria, Vol. 32, N0 1. Pp. 1-6.

Basu, P. (2006). Improving Access to Finance for India's Rural Poor, Directions in Development No.36448, World Bank, Washington.D.C. Pp.1-88. 
Beck T. and la Torre (2006). the Basic Analytics of Access to Financial Services, Paper at the Latin American Regional Study on Access to Finance, World Bank, Washington D.C. Pp1-49.

Bungalawala, Zamila (2011) Young, Educated and Dependent on the Public Sector, Meeting Graduate Aspiration and Diversifying Employment in Qatar and the UAE, Brookings Doha Centre Analysis Paper No 4 December

Burgess, R. and Pande, R.(2003). Do Rural Banks Matter? Evidence from the Indian Social Banking Experiment. Research Paper.3-8.

Butler, W.A. and Cornaggia, J.(2008). Does Access to External Finance Improve Productivity? Evidence from a Natural Experiment. Paper Presented at International Seminar Held at Baylor University, USA. 2-9.

Central Bank of Nigeria (2005).. Microfinance Policy, Regulatory and Supervisory, Framework for Nigeria, Abuja Nigeria Pp-2-33.

Classens, S., Dabos, G.,Klingebile, D. and Laeven, L. (2003). The Growing Importance of Networks in Finance and its Effect of Competition, Nagurnay, A. (Ed): Innovations in Financial and Economics Networks, Edward Elgar Publishers, Northampton. Pp110-135.

Coenjaerts, C., C. Ernst, M. Fortny, and D. Rei (2009) Youth Employment in "Promoting Propoor Growth" OECD

De la Torre, A. and Schmukler, S. (2006). Innovative Experience in Access: Market Friendly Roles for the Visible Hand. Latin America Regional Study. World Bank. Pp12-17.

Devkota, D. (2006). Access to and Control over Household Resources: a Consistency Check Using Gender Analysis and Household Survey Data. Journal of Agricultural Research. Vol.7. No1. Pp99-107.

Dromel, N. L. , E. Kolakez and E. Lehmann (2010) Credit Constraints and the Persistence of Unemployment, Labour Economics, 17, pp 823-834

Egwuatu, B. (2008). Reducing Poverty through Better Credit Delivery: The Asian Experience. Bullion, CBN. Pp8-14.

Fleising, H. and De la pena, N. (2003). Legal and Regulatory Requirements for Effective Rural Financial Markets, "Paving the Way Forwards": an International Conference on Best Practice in Rural Finance. Washington D.C. Pp12-16.

Gonzalez-Vega, C. (2003). Deepening Rural Financial Markets: Macroeconomic, Policy and Political Dimensions. "Paving the Way forward": an International Conference on Best Practices in Rural Finance. Washington. D. Pp3-52.

Hicks, John. R., (1969). A Theory of Economic History. Oxford, Calderon Press.

Ibrahim, S. S. (2011), an Investigation into the Determinants of Access to Finance in Rural Areas of Katsina State. Unpublished M.Sc. Dissertation, Usmanu Danfodiyo University, Sokoto.

IPAR (2007). Poverty Reduction Through Enhanced Access to Financial Services: Case Study of Botswana, Kenya and Namibia. Occasional Paper No.010/2007.

Jimba, D. I. (2007), Exigencies of Youth Empowerment for Sustainable Development in Nigeria. In Agwuama (Eds), the Contemporary Issues and the Challenges of Sustainable Development in the New Millennium: the Nigerian Experience.

Kaino, T. (2005). Rural Credit Market in Myanmar: A Study of Formal and Non-formal Lenders. Asian Journal of Agriculture and Development. Vol.4. No.1. Pp.3-15.

Ladipo, M. (2008). Enhancing Financial Innovation and Access. Results of survey of Nigerian Adult Population. Pp2-8.

Nasr, S. (2006). Access to Finance and Economic Growth in Egypt. A Report on Middle East and North Africa. The World Bank. Washington D.C. Pp.40-180. 
http//siteresources.world.org/inegypt/resources/access_to_finance.pdf. Accessed $25^{\text {th }}$ July 2010.

Naved, R.(1994) Empowerment of Women: Listening to the Voices of Women. The Bangladesh Development Studies. XX11(2).

McKinnon, R. (1973). Money and Capital in Economic Development, Washington, D.C. The Brookings Institutions. Pp3-15. $\underline{\text { http://books.google.com/books?id=erOVIDIY1jEC\&printsec }=\text { frontcover\&dq }=\text { Money }}$ + and + capital + in + economic + development\&source=bl\&ots=LY4frn $6 \mathrm{~F} 9 \& \operatorname{sig}=\mathrm{kKjsyD}$

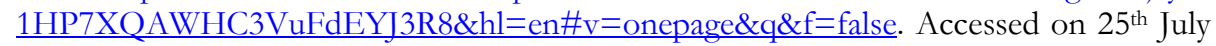
2010.

Olayide, S., Eweka, A. and Osagie, B. (1980). Nigeria's Small Farmer: Problems and Prospects in Integrated Rural Development. Centre for Agricultural research In Development, University of Ibadan, Nigeria. Pp3-11.

Rajan, R. and Zingales, L. (2003). Saving Capitalism from the Capitalists, Crown Business, New York. http://www.savingcapitalism.com/capintro.pdf. Accessed 23 ${ }^{\text {rd }}$ September, 2010

Robinson, J. ( 1952). "The Generalization of the General Theory," In: the Rate of Interest and Other Essays, London, Macmillan.

Sacerdot, E. (2005). Access to Bank Credit in Sub-Saharan Africa: Key Issues and Reform Strategies. IMF Working Paper, WP/05/166. Pp3-22.

Sancho, A. (1996). Policies and Progress for Social Human Development. A Handbook by United Nation world Summit for Social Development. International Centre for Economic Growth, Sans Francisco. Pp3-7.

Schumpeter, J. A,(1912). "The Theory of Economic Development: An Inquiry Into Profits, Capital, Credit, Interest and the Business Cycle." Leipzig, Germany, Dunker \& Humboldt.

Sebopetji,T.O. and Belete, A.(2009). An Application of Probit Analysis to Factors Affecting Small-Scale Farmers' Decision to take Credit: a Case Study of Greater Letabo Local Municipality in South Africa. Jounal of Agricultural Research. Vol.4(8). Pp718-723.

Stiglitz, J.(1993). The Role of the State in Financial Markets, Proceeding of the World Bank Annual Conference on Development Economics, Pp 19-62.

Subrahmanyam, Gita (2011) Tackling Youth unemployment in the Magrib, AfDB Economic Policy Brief

Todaro, M.P. (2000). Economic Development. Seventh Ed. Addison Wesley Longman, Inc.

The World Youth Report (2005). Young People Today and in 2015. New York: United Nations.

Zaman, H.(1999) Assessing the Poverty and Vulnerability Impact of Micro-Credit in Bangladesh: a Case Study of BRAC. WPNo. 2145. World Bank. Pp.2-7. 
